\title{
Mosquito Frequency and Feeding Habits in an Enzootic Canine Dirofilariasis Area in Niterói, State of Rio de Janeiro, Brazil
}

\author{
Norma Labarthe/ ${ }^{+}$, Maria Lúcia Serrão*, Yuri Fontenele Melo, \\ Sebastião José de Oliveira**, Ricardo Lourenço-de-Oliveira*
}

Faculdade de Veterinária, Centro de Ciências Médicas, Universidade Federal Fluminense, Rua Vital Brazil Filho 64, 24230-340 Niterói, RJ, Brasil *Laboratório de Transmissores de Hematozoários **Coleção Entomológica, Departamento de Entomologia, Instituto Oswaldo Cruz, Av. Brasil 4365, 21045-900 Rio de Janeiro, RJ, Brasil

Heartworm, a chronic fatal mosquito-borne canine disease, is frequently diagnosed in dogs from the State of Rio de Janeiro, where its prevalence is $29.7 \%$ in the city of Niterói. Nevertheless it is rarely detected in cats (0.8\%) from the same state. Dogs are the primary source of infection to mosquitoes, because cats either do not demonstrate microfilaremia or it is too low and transient for transmission. A mosquito survey was conducted in Itacoatiara, Niterói, from March 1995 to February 1996, using canine, feline and human baits. A total of 21 mosquito species $(3,888$ females) was collected and biting frequency was highest at dusk. The four species collected most frequently (88.9\%) were: Aedes taeniorhynchus (30\% of the total catch; with the peak in May/June); Culex quinquefasciatus (22.5\%; August/October); Aedes scapularis (19.4\%; August, October/November and January) and Culex declarator (17\%; November/January). Human baits were attractive to these species and dogs were significantly more attractive to them than cats. Ae. taeniorhynchus, Cx. quinquefasciatus, Ae. scapularis, Cx. declarator and Cx. nigripalpus are the most likely mosquito species to transmit Dirofilaria immitis parasites to dogs and may transmit the parasite to humans. It is also suggested that the vector to cats belongs to the genus Culex.

Key words: Dirofilaria immitis - heartworm - mosquito frequency - mosquito feeding habits - canine - feline

Dirofilariasis (Dirofilaria immitis Leidy) is a widely spread mosquito-borne nematodiasis of dogs and cats. Canine heartworm is enzootic in many areas worldwide (Guerrero et al. 1992a). However, while feline dirofilariasis is much less common, it is thought to be increasing in prevalence and distribution (Guerrero et al. 1992b). Presently it is accepted that feline heartworm infection parallels that of dogs in a given area, although at a lower infection rate (Dillon 1988, Elkins \& Kadel 1988), even though cats are considerably susceptible to infection under experimental conditions (McCall et al. 1992).

Dogs are considered to be the primary source of infection to mosquitoes because cats either do not demonstrate microfilaremia or it is too low and transient for them to be considered efficient reservoirs (Donahoe 1975, Wong et al. 1983, Dillon 1986). Therefore, the heartworm's life cycle is dependent upon microfilaremic dogs, abundance

${ }^{+}$Corresponding author. Fax: + 55-21-295.2052

Received 20 May 1997

Accepted 12 November 1997 of competent vectors, favorable environmental conditions and a susceptible population of definitive hosts (Genchi et al. 1992, Guerrero et al. 1992b, Knight \& Lok 1995).

Over 60 mosquito species have been shown to be able to transmit Dirofilaria immitis under experimental or natural conditions (Ludlam et al. 1970). In Brazil, few studies on heartworm vectors have been conducted. $D$. immitis can develop infective larvae in Aedes fluviatilis (Lutz) under laboratory conditions, although it is not likely to be an efficient vector in nature (Kasai \& Williams 1986). Nevertheless, in an enzootic area in the city of Rio de Janeiro, 569 mosquitoes belonging to 20 species were dissected by Lourenço-de-Oliveira and Deane (1995) and two of them were found naturally infected by $D$. immitis-like larvae: one Ae. scapularis (Rondani) contained a single sausage-stage larva in the Malpighian tubules and one Ae. tae-niorhynchus (Wiedemann) had five third stage larvae in the lumen of the tubules. Based on these data, these two species were recognized as likely vectors in the study area. Further, it was suggested that field studies to determine the mosquito species attracted to dogs should be conducted in enzootic areas, as well as studies to determine the 
susceptibility of these mosquitoes to $D$. immitis parasites.

It is well documented that mosquito species populations have blood feeding preferences. Some mosquito species are very restrictive and will feed only on certain hosts while others are catholic and will choose upon their preference according to host abundance (Deane 1951, Edman \& Bidlingmayer 1969, Aragão 1975, Forattini et al. 1987a). In Brazil, for instance, it has been shown that Culex quinquefasciatus Say, an endophilic and synanthropic species, feeds on mammals and birds and that among those hosts it has a preference for feeding on humans, although they frequently feed on dogs and less frequently on cats (Deane 1951, Rachou 1956, Forattini et al. 1987a). Ae. scapularis was also shown to feed on human, canine and feline hosts, besides being regarded as a hemisynanthropic species (Forattini et al. 1987b, 1993, 1995).

It has been proposed that mosquitoes which serve as vectors for D. immitis may have a low preference for cats or that cats do not tolerate mosquito bites as well as dogs do, which would decrease the probability for cats to become infected (Donahoe 1975). In a heartworm enzootic area of Italy, dogs and cats were compared for their attractiveness to mosquitoes. It was shown that the largest numbers of captures were always from dog: 1,396 mosquitoes captured in the dog-baited trap and 338 in the cat-baited trap (Genchi et al. 1992).

In the State of Rio de Janeiro, heartworm is frequently diagnosed in dogs, where its prevalence is $29.7 \%$ in the city of Niterói and $14 \%$ in the city of Rio de Janeiro (Labarthe et al. 1997a). On the other hand, it is rarely reported in cats from the State, where the known prevalence is $0.8 \%$ (Labarthe et al. 1997b).

Because (1) an evaluation of mosquito preference between dogs and cats has never been conducted in heartworm endemic areas of Brazil, (2) cats are susceptible to D. immitis infection even if they are infected at a lower level than dogs are, and (3) it seems like there is a mosquito host preference that can determine such a difference in infection rate, a longitudinal year-round study was initiated to elucidate mosquito host preferences and biting frequencies for dogs and cats, as well as humans.

\section{MATERIALS AND METHODS}

Mosquitoes were collected in Itacoatiara, in the municipality of Niterói, Brazil $\left(22^{\circ} .55^{\prime} \mathrm{S}\right.$ $43^{\circ} .03^{\prime} \mathrm{W}$ ), a coastal residential district along a 700 $\mathrm{m}$ beach and settled on a narrow strip of level land of quaternary sedimentation surrounded by mountains. The area is characterized by lagoons, closed by barrier bars, that straighten the coastline (Fig.
1). The mountain vegetation is composed of patches of primary and secondary rain forest while the low land is mostly covered by barrier beach vegetation. From March 1995 until February 1996, mosquitoes were captured four days each month using a black and white female $\operatorname{dog}(7 \mathrm{~kg})$, a black and white female cat $(3.5 \mathrm{~kg})$ and two human volunteers.

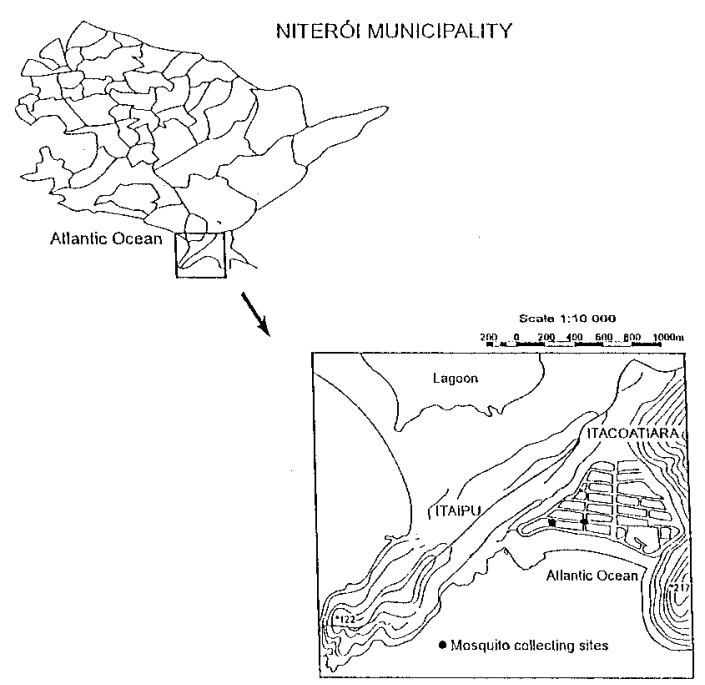

Fig. 1: map showing the study site. Further information upon geographical localization can be found in Labarthe et al. (1997a).

One dog-and one cat-baited wooden mosquito trap $(75 \times 100 \times 120 \mathrm{~cm})$, were designed with two Egyptian type baffles (Bates 1949) on each side (allowing diffusion of host emanations to the environment) with associated horizontal slots to allow mosquitoes to enter the trap. The traps were operated for $3 \mathrm{hr}$ during dawn (starting at daybreak) and dusk (starting $30 \mathrm{~min}$ before sunset). The dog and the cat were kept in individual traps, but protected from mosquito bites in an inner restraining wire cage (50x50x50 cm) entirely covered by mosquito net and suspended $45 \mathrm{~cm}$ from the cage floor. The two traps were placed $25 \mathrm{~m}$ apart, outside a residence. Every collection day, the position of the dog- and the cat-baited mosquito traps were interchanged. After the $3 \mathrm{hr}$ collection period, the animals were carefully removed from the traps and the trapped mosquitoes were collected with aspirators. Half an hour after setting the traps, two humans stood outdoors, about $200 \mathrm{~m}$ from the dogand cat-baited traps, and captured mosquitoes directly from their own bodies for $1 \mathrm{hr}$. In the afternoon (1:00-3:00 p.m.), mosquitoes were captured while landing on the dog, cat or humans. During this collection period, the dog and the cat were kept 
in separate wire cages, with the human volunteers outside and collecting mosquitoes off themselves and the animals concurrently.

Mosquitoes were kept in carton cages of $8.5 \mathrm{~cm}$ diameter at $28^{\circ} \mathrm{C}, 80 \%$ relative humidity and provided a $10 \%$ glucose solution. After being anesthetized with chloroform vapor, they were identified using taxonomic keys of Lane (1953) and Consoli and Lourenço-de-Oliveira (1994). Identifications were confirmed by comparison with reared adult specimens with associated immature stages, collected in the study area. Monthly rainfall and temperature data were obtained from the Instituto Nacional de Meteorologia, from the Maricá station $\left(22^{\circ} .55^{\prime} \mathrm{S} 42^{\circ} .49^{\prime} \mathrm{W}\right)$.

For the statistical analysis, only mosquitoes showing an overall frequency higher than $1 \%$ were considered. The frequency distribution was used to analyze the discrete data, the $\mathrm{Z}$ test was used to compare two proportions (Rodrigues 1993) and the Williams' mean to analyze serial data (Williams 1937, Haddow 1954, 1960).

\section{RESULTS}

A total of 3,888 female mosquitoes belonging to 21 species were collected from the three different baits (Table I). Species collected more fre- quently than $1 \%$ were compared to each other. The species most frequently collected in decending order were: Ae. taeniorhynchus; Cx. quinquefasciatus; Ae. scapularis; $C x$. declarator; $C x$. nigripalpus; Ae. albopictus and Wy. bourrouli. Their frequencies and Williams' means demonstrate large distribution differences between $A e$. taeniorhynchus and Wy. bourrouli (Tables II, III, IV, Fig. 2).

Dogs were significantly more attractive than cats to Ae. taeniorhynchus, $C x$. quinquefasciatus, Ae. scapularis, $C x$. declarator and Cx. nigripalpus. More Ae. albopictus and Wy. bourrouli were collected on cats than dogs, although these mosquitoes were rarely caught on either bait and their low number of captures did not allow statistical treatment. The seven above mentioned species were also caught from the two humans, but due to methodological differences these data were not compared statistically to the animal baits (Table V). All seven species, except Wy. bourrouli, were more active during dusk than the other collecting times, and none of the Culex species was seen attacking any of the baits during the afternoon (Tables VI,VII).

When the Williams' means of the seven most frequent mosquito species were correlated with the mean temperature, only Ae. albopictus showed a

TABLE I

Frequency of mosquitoes captured in Itacoatiara, Niterói, RJ, Brazil from human, canine and feline baits, from March 1995 to February 1996

\begin{tabular}{lcc}
\hline Species & Frequency & $\%$ \\
\hline Aedes taeniorhynchus (Wiedemann) & 1,168 & 30.0 \\
Culex quinquefasciatus Say & 876 & 22.5 \\
Aedes scapularis (Rondani) & 756 & 19.4 \\
Culex declarator Dyar \& Knab & 660 & 17.0 \\
Culex nigripalpus Theobald & 121 & 3.1 \\
Aedes albopictus (Skuse) & 109 & 2.8 \\
Wyeomyia bourrouli (Lutz) & 45 & 1.2 \\
Phoniomyia spp. & 38 & 1.0 \\
Culex bidens Dyar & 30 & 0.8 \\
Culex coronator Dyar \& Knab & 28 & 0.7 \\
Culex pilosus (Dyar \& Knab) & 19 & 0.5 \\
Culex saltanensis Dyar & 18 & 0.5 \\
Limatus durhami Theobald & 6 & 0.2 \\
Culex lygrus Root & 3 & 0.1 \\
Psorophora sp. & 3 & 0.1 \\
Rhunchomyia sp. & 3 & -1 \\
Aedeomyia squamipennis (Lynch Arribalzaga) & $b$ \\
Anopheles aquasalis Curry & 1 & $-b$ \\
Coquellettidia venezuelensis (Theobald) & 1 & $-b$ \\
Mansonia titillans (Walker) & $-b$ \\
Wyeomyia confusa (Lutz) & 1 & $-b$ \\
Total & 1 & 100 \\
\hline
\end{tabular}

$a$ : including Ph. davisi Lane \& Cerqueira, Ph. deanei Lourenço-de-Oliveira and Ph. edwardsi Lane \& Cerqueira; $b$ : less than $0.1 \%$. 
Mosquitoes in a Canine Dirofilariasis Area in Brazil • Norma Labarthe et al.
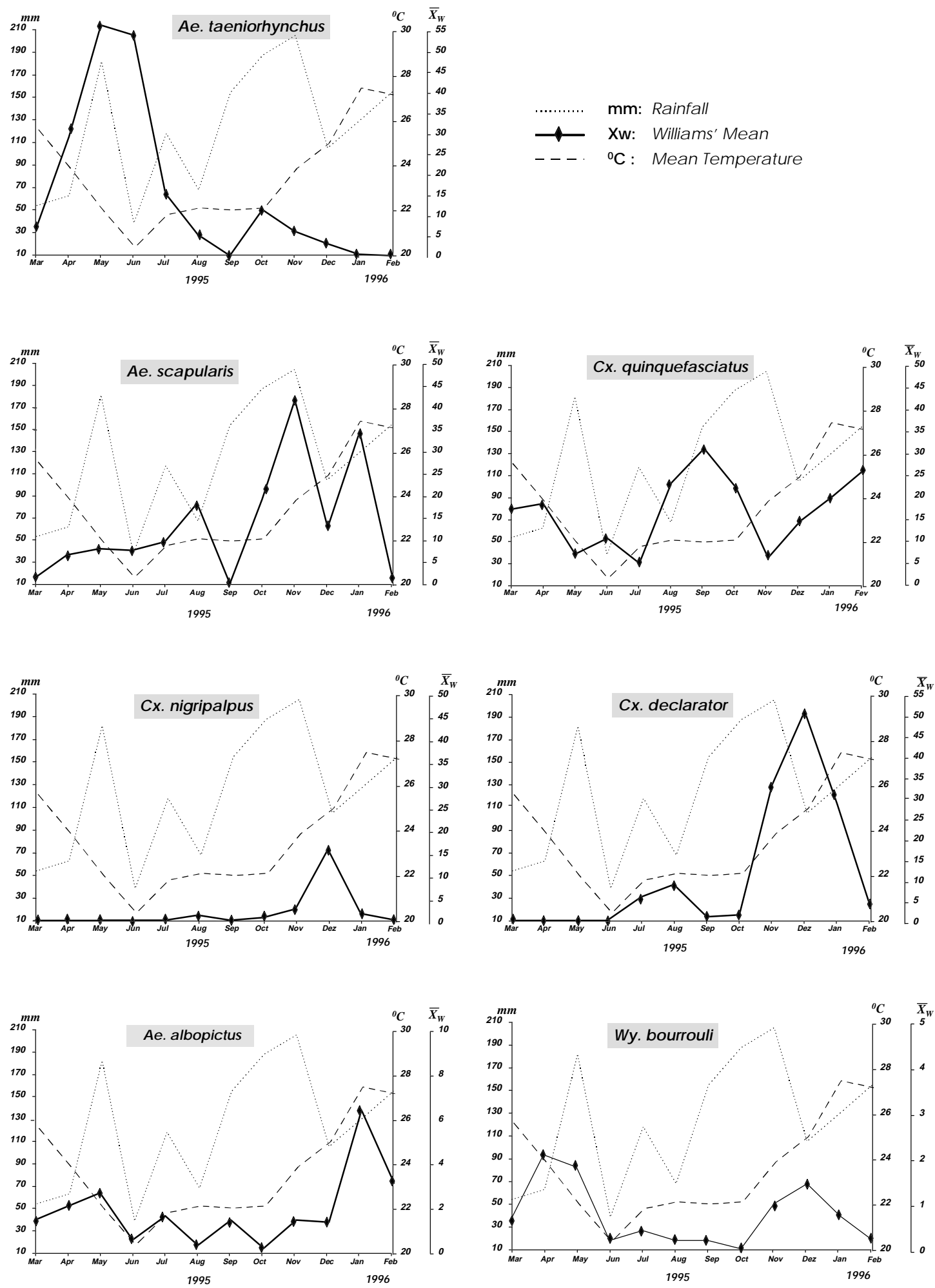

Fig. 2: monthly Williams' means of the seven most frequently collected mosquito species on canine, feline and human baits, at Itacoatiara, Niterói, Rio de Janeiro, Brazil (Note that there are different scales). 
TABLE II

Monthly distribution of females of the most frequent mosquito species captured on canine bait in Itacoatiara, Niterói, RJ, Brazil, from March 1995 to February 1996

\begin{tabular}{|c|c|c|c|c|c|c|c|c|c|c|c|c|c|}
\hline & & \multicolumn{8}{|c|}{1995} & \multirow[b]{2}{*}{ Nov } & \multirow[b]{2}{*}{ Dec } & \multicolumn{2}{|c|}{1996} \\
\hline & & Mar & Apr & May & Jun & Jul & Aug & Sep & Oct & & & Jan & Feb \\
\hline \multirow{2}{*}{$\begin{array}{l}\text { Aedes } \\
\text { taeniorhynchus }\end{array}$} & Freq. & 4 & 74 & 31 & 46 & 20 & 4 & 0 & 9 & 3 & 4 & 0 & 0 \\
\hline & Xw & 0.68 & 3.57 & $7 \quad 5.88$ & 10.82 & 3.29 & 0.68 & 0 & 2.09 & 0.32 & 0.86 & 0 & 0 \\
\hline \multirow{2}{*}{$\begin{array}{l}\text { Culex } \\
\text { quinquefasciatus }\end{array}$} & Freq. & 28 & 39 & 16 & 26 & 14 & 50 & 93 & 73 & 18 & 41 & 44 & 32 \\
\hline & Xw & 6.0 & 8.72 & 2.76 & 6.29 & 2.55 & 9.06 & 17.62 & 17.1 & 3.7 & 10.09 & 10.28 & 6.83 \\
\hline \multirow{2}{*}{ Ae. scapularis } & Freq. & 1 & 8 & 4 & 2 & 8 & 12 & 0 & 27 & 19 & 3 & & 0 \\
\hline & Xw & 0.19 & 1.4 & 0.74 & 0.41 & 0.99 & 1.98 & 0 & 6.33 & 4.34 & 0.57 & 1.21 & 0 \\
\hline \multirow[t]{2}{*}{$C x$. declarator } & Freq. & 0 & 0 & 0 & 1 & 30 & 22 & 2 & 5 & 131 & 128 & & 7 \\
\hline & Xw & 0 & 0 & 0 & 0.19 & 3.68 & 4.37 & 0.32 & 1.06 & 24.12 & 26.7 & 14.49 & 1.37 \\
\hline \multirow[t]{2}{*}{$C x$. nigripalpus } & Freq. & 0 & 0 & 1 & 0 & 1 & 6 & 0 & 4 & 16 & 39 & 5 & 0 \\
\hline & Xw & 0 & 0 & 0.19 & 0 & 0.19 & 1.21 & 0 & 0.86 & 1.74 & 9.11 & 1.06 & 0 \\
\hline \multirow[t]{2}{*}{ Ae. albopictus } & Freq. & 0 & 0 & 0 & 0 & 0 & 0 & 0 & 0 & 0 & 0 & 0 & 0 \\
\hline & Xw & 0 & 0 & 0 & 0 & 0 & 0 & 0 & 0 & 0 & 0 & 0 & 0 \\
\hline \multirow{2}{*}{$\begin{array}{l}\text { Wyeomyia } \\
\text { bourrouli }\end{array}$} & Freq. & 0 & 0 & 1 & 0 & 0 & 0 & 0 & 0 & 0 & 0 & 0 & 0 \\
\hline & Xw & 0 & 0 & 0.19 & 0 & 0 & 0 & 0 & 0 & 0 & 0 & 0 & 0 \\
\hline
\end{tabular}

Freq: frequency; Xw: Williams'mean.

\section{TABLE III}

Monthly distribution of females of the most frequent mosquito species captured on feline bait in Itacoatiara, Niterói, RJ, Brazil, from March 1995 to February 1996

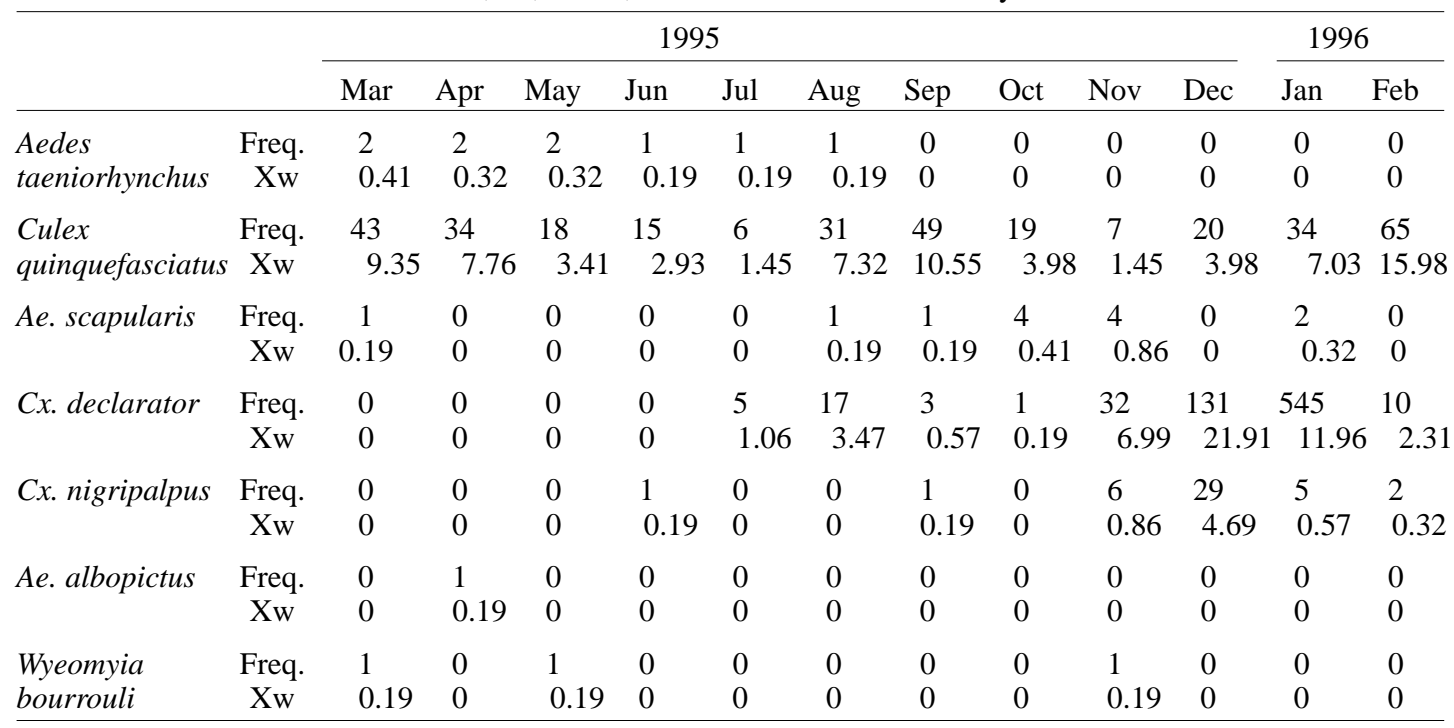

Freq.: frequency; Xw: Williams'mean.

significant $(\mathrm{a}=1 \%)$ positive correlation. When they were correlated with the rainfall, no species had a significant level of correlation, although Ae. scapularis showed population increases following a rise in rainfall, especially when the mean temperature was above $22^{\circ} \mathrm{C}$ (Fig. 2).

\section{DISCUSSION}

When considering their monthly frequencies during the year, Ae. taeniorhynchus showed only one population peak (April-June), while Ae. scapularis showed a multivoltine pattern with higher density from August to January, although it 


\section{TABLE IV}

Monthly distribution of females of the most frequent mosquito species captured on human bait in Itacoatiara, Niterói, RJ, Brazil, from March 1995 to February 1996

\begin{tabular}{|c|c|c|c|c|c|c|c|c|c|c|c|c|c|}
\hline & \multicolumn{8}{|c|}{1995} & & & \multicolumn{2}{|l|}{1996} \\
\hline & & Mar & Apr & May & Jun & Jul & Aug & Sep & Oct & Nov & Dec & Jan & Feb \\
\hline $\begin{array}{l}\text { Aedes } \\
\text { taeniorhynchus }\end{array}$ & $\begin{array}{c}\text { Freq. } \\
\text { Xw }\end{array}$ & $\begin{array}{l}44 \\
5.02\end{array}$ & $\begin{array}{l}374 \\
25.3\end{array}$ & $\begin{array}{l}198 \\
46.59\end{array}$ & $\begin{array}{l}174 \\
40.2\end{array}$ & $\begin{array}{l}77 \\
111.88\end{array}$ & $\begin{array}{l}28 \\
4.37\end{array}$ & $\begin{array}{l}0 \\
0\end{array}$ & $\begin{array}{l}35 \\
8.6\end{array}$ & $\begin{array}{l}21 \\
5.09\end{array}$ & $\begin{array}{l}11 \\
1.82\end{array}$ & $\begin{array}{l}2 \\
0.32\end{array}$ & $\begin{array}{l}0 \\
0\end{array}$ \\
\hline $\begin{array}{l}\text { Culex } \\
\text { quinquefasciatus }\end{array}$ & $\begin{array}{l}\text { Freq. } \\
\text { Xw }\end{array}$ & $\begin{array}{l}2 \\
0.41\end{array}$ & $\begin{array}{l}4 \\
0.5\end{array}$ & $\begin{array}{l}0 \\
0\end{array}$ & $\begin{array}{l}3 \\
0.57\end{array}$ & $\begin{array}{l}3 \\
0.68\end{array}$ & $\begin{array}{l}15 \\
2.76\end{array}$ & $\begin{array}{l}11 \\
0.86\end{array}$ & $\begin{array}{l}3 \\
0.68\end{array}$ & $\begin{array}{l}3 \\
0.57\end{array}$ & $\begin{array}{l}1 \\
0.19\end{array}$ & $\begin{array}{l}5 \\
1.06\end{array}$ & $\begin{array}{l}11 \\
2.47\end{array}$ \\
\hline Ae. scapularis & $\begin{array}{c}\text { Freq. } \\
\mathrm{Xw}\end{array}$ & $\begin{array}{l}6 \\
0.97\end{array}$ & $\begin{array}{l}33 \\
5.72\end{array}$ & $\begin{array}{l}37 \\
7.81\end{array}$ & $\begin{array}{l}35 \\
7.76\end{array}$ & $\begin{array}{l}49 \\
8.72\end{array}$ & $\begin{array}{l}82 \\
16.28\end{array}$ & $\begin{array}{l}2 \\
0.32\end{array}$ & $\begin{array}{l}54 \\
11.88\end{array}$ & $\begin{array}{l}153 \\
35.94\end{array}$ & $\begin{array}{l}53 \\
+12.41\end{array}$ & $\begin{array}{l}141 \\
33.08\end{array}$ & $\begin{array}{l}8 \\
1.51\end{array}$ \\
\hline$C x$. declarator & $\begin{array}{l}\text { Freq. } \\
\mathrm{Xw}\end{array}$ & $\begin{array}{l}0 \\
0\end{array}$ & $\begin{array}{l}0 \\
0\end{array}$ & $\begin{array}{l}0 \\
0\end{array}$ & $\begin{array}{l}0 \\
0\end{array}$ & $\begin{array}{l}0 \\
0\end{array}$ & $\begin{array}{l}1 \\
0.19\end{array}$ & $\begin{array}{l}0 \\
0\end{array}$ & $\begin{array}{l}0 \\
0\end{array}$ & $\begin{array}{l}1 \\
0.19\end{array}$ & $\begin{array}{l}1 \\
0.19\end{array}$ & $\begin{array}{l}1 \\
0.19\end{array}$ & $\begin{array}{l}0 \\
0\end{array}$ \\
\hline Cx. nigripalpus & $\begin{array}{c}\text { Freq. } \\
\text { Xw }\end{array}$ & $\begin{array}{l}0 \\
0\end{array}$ & $\begin{array}{l}0 \\
0\end{array}$ & $\begin{array}{l}0 \\
0\end{array}$ & $\begin{array}{l}1 \\
0.19\end{array}$ & $\begin{array}{l}0 \\
0\end{array}$ & $\begin{array}{l}1 \\
0.19\end{array}$ & $\begin{array}{l}0 \\
0\end{array}$ & $\begin{array}{l}0 \\
0\end{array}$ & $\begin{array}{l}2 \\
0.41\end{array}$ & $\begin{array}{l}0 \\
0\end{array}$ & $\begin{array}{l}1 \\
0.19\end{array}$ & $\begin{array}{l}0 \\
0\end{array}$ \\
\hline Ae. albopictus & $\begin{array}{c}\text { Freq. } \\
\text { Xw }\end{array}$ & $\begin{array}{l}9 \\
1.54\end{array}$ & $\begin{array}{l}10 \\
1.92\end{array}$ & $\begin{array}{l}12 \\
2.09\end{array}$ & $\begin{array}{l}3 \\
0.57\end{array}$ & $\begin{array}{l}8 \\
1.63\end{array}$ & $\begin{array}{l}2 \\
0.32\end{array}$ & $\begin{array}{l}6 \\
1.45\end{array}$ & $\begin{array}{l}1 \\
0.19\end{array}$ & $\begin{array}{l}10 \\
1.45\end{array}$ & $\begin{array}{l}7 \\
1.37\end{array}$ & $\begin{array}{l}27 \\
6.20\end{array}$ & $\begin{array}{l}13 \\
3.12\end{array}$ \\
\hline $\begin{array}{l}\text { Wyeomyia } \\
\text { bourrouli }\end{array}$ & $\begin{array}{c}\text { Freq. } \\
\text { Xw }\end{array}$ & $\begin{array}{l}5 \\
0.57\end{array}$ & $\begin{array}{l}9 \\
2.09\end{array}$ & $\begin{array}{l}8 \\
1.29\end{array}$ & $\begin{array}{l}1 \\
0.19\end{array}$ & $\begin{array}{l}2 \\
0.41\end{array}$ & $\begin{array}{l}1 \\
0.19\end{array}$ & $\begin{array}{l}1 \\
0.19\end{array}$ & $\begin{array}{l}0 \\
0\end{array}$ & $\begin{array}{l}3 \\
0.68\end{array}$ & $\begin{array}{l}6 \\
1.45\end{array}$ & $\begin{array}{l}4 \\
0.74\end{array}$ & $\begin{array}{l}1 \\
0.19\end{array}$ \\
\hline
\end{tabular}

Freq.: frequency; Xw: Williams'mean.

TABLE V

Total number of female mosquitoes from the most frequent species captured on dog, cat and human baits in Itacoatiara, Niterói, RJ, Brazil, from March 1995 to February 1996

\begin{tabular}{|c|c|c|c|c|c|c|c|c|}
\hline \multirow[b]{2}{*}{ Bait } & \multicolumn{7}{|c|}{ Species } & \multirow[b]{2}{*}{ Total } \\
\hline & $\begin{array}{c}\text { Aedes } \\
\text { taeniorhynchus }\end{array}$ & $\begin{array}{c}\text { Culex } \\
\text { quinquefasciatus }\end{array}$ & $\begin{array}{c}\text { Ae. } \\
\text { scapularis }\end{array}$ & $\begin{array}{c}\text { Cx. } \\
\text { declarator }\end{array}$ & $\begin{array}{c}C x . \\
\text { nigripalpus }\end{array}$ & $\begin{array}{c}\text { Ae. } \\
\text { albopictus }\end{array}$ & $\begin{array}{l}\text { Wyeomyia }^{b} \\
\text { bourrouli }\end{array}$ & \\
\hline Dog & 195 & 474 & 90 & 403 & 72 & 0 & 1 & 1,235 \\
\hline Cat & 9 & 341 & 13 & 253 & 44 & 1 & 3 & 664 \\
\hline Sig. & ++ & ++ & ++ & ++ & + & - & - & - \\
\hline $\operatorname{Man}^{a}$ & 964 & 61 & 653 & 4 & 5 & 108 & 41 & 1,836 \\
\hline Total & 1,168 & 876 & 756 & 660 & 121 & 109 & 45 & 3,735 \\
\hline
\end{tabular}

$a$ : two humans. These data were not analyzed statistically due to methodological differences; $b$ : not compared statistically due to the small number of individuals captured; Sig.: significance level; + : significant at $\mathrm{p}<0.05$; ++ : significant at $\mathrm{p}<0.01$.

\section{TABLE VI}

Number of female mosquitoes from the most frequent species captured on dog, cat and human baits during dawn, dusk and afternoon in Itacoatiara, Niterói, RJ, Brazil, from March 1995 to February 1996

\begin{tabular}{|c|c|c|c|c|}
\hline Period/Species & Dawn & Dusk & Sig. & Afternoon $^{a}$ \\
\hline Aedes taeniorhynchus & 130 & 530 & ++ & 508 \\
\hline Culex quinquefasciatus & 32 & 844 & ++ & 0 \\
\hline Ae. scapularis & 169 & 430 & ++ & 157 \\
\hline$C x$. declarator & 6 & 654 & ++ & 0 \\
\hline Cx. nigripalpus & 4 & 117 & ++ & 0 \\
\hline Ae. albopictus $b$ & 35 & 47 & - & 27 \\
\hline Wyeomyia bourrouli $^{b}$ & 25 & 5 & - & 15 \\
\hline Total & 401 & 2,627 & - & 707 \\
\hline
\end{tabular}

$a$ : data for afternoon were not analyzed statistically due to methodological differences, and also because fewer hours were spent with capture; $b$ : not compared statistically due to the small number of individuals caught; Sig.: significance level; ++: significant at $\mathrm{p}<0.01$. 
TABLE VII

Number of female mosquitoes from the most frequent species captured on dog (D), cat (C) and human (H) baits during dawn, afternoon and dusk, in Itacoatiara, Niterói, RJ, Brazil, from March 1995 to February 1996

\begin{tabular}{|c|c|c|c|c|c|c|c|c|c|}
\hline & \multicolumn{3}{|c|}{ Dawn } & \multicolumn{3}{|c|}{ Afternoon } & \multicolumn{3}{|c|}{ Dusk } \\
\hline & $\mathrm{D}$ & $\mathrm{C}$ & $\mathrm{H}$ & $\mathrm{D}$ & $\mathrm{C}$ & $\mathrm{H}$ & $\mathrm{D}$ & $\mathrm{C}$ & $\mathrm{H}$ \\
\hline Ae. taeniorhynchus & 13 & 5 & 112 & 154 & 0 & 354 & 28 & 4 & 498 \\
\hline Cx. quinquefasciatus & 17 & 15 & 0 & 0 & 0 & 0 & 457 & 326 & 61 \\
\hline Ae. scapularis & 9 & 3 & 157 & 52 & 0 & 105 & 29 & 10 & 391 \\
\hline Cx. declarator & 5 & 1 & 0 & 0 & 0 & 0 & 398 & 252 & 4 \\
\hline Cx. nigripalpus & 3 & 0 & 1 & 0 & 0 & 0 & 69 & 44 & 4 \\
\hline Ae. albopictus & 0 & 0 & 35 & 0 & 0 & 27 & 0 & 1 & 46 \\
\hline Wy. bourrouli & 0 & 0 & 25 & 1 & 2 & 12 & 0 & 1 & 4 \\
\hline Total & 47 & 24 & 330 & 206 & 2 & 498 & 981 & 638 & 1,008 \\
\hline
\end{tabular}

Ae: Aedes; Cx: Culex; Wy: Wyeomyia.

was captured throughout the year (Fig. 2). This phenomenon was similar to the one described by Lourenço-de-Oliveira et al. (1985) in a coastal lowland heartworm enzootic area of the city of Rio de Janeiro.

$C x$. quinquefasciatus also demonstrated a multivoltine pattern and was captured year-round. $C x$. declarator had a monthly frequency similar to $C x$. quinquefasciatus, but it had only one peak in numbers during the year (November-January).

Mosquitoes were attracted in higher numbers by each bait when mosquito densities were greatest, despite any interference of individual baits (Tables II, III, IV). Overall, mosquitoes were attracted to the animals according to their own preferences, but always in proportion with its population density. As stated by other workers, in order to be a heartworm vector, besides being resistant to infection but yet susceptible enough to allow larvae development, a mosquito species must feed on dogs, be well adapted to the region and be abundant and preferably multivoltine (Ludlam et al. 1970, Christensen 1977, 1978, 1981, Otto \& Jachowski 1980). Accordingly, the four species mentioned above could be looked upon as those most likely to be significant vectors of dirofilariasis, especially the two species with multivoltine patterns.

Ae. albopictus and Wy. bourrouli preferred humans to either dog or cat (Table V), and were infrequently captured on either of the animal baits. This suggests that these two species are not primary vectors of $D$. immitis. Nevertheless, attention must be given to Ae. albopictus, a species captured in small numbers, but present year-round and showing a positive correlation between it's densities and rainfall (Fig. 2). This species, recently reintroduced into Brazil, is reported to be a vector of dirofilariasis in the USA and Japan (Kartman 1953, Apperson et al. 1989, Konishi 1989a, b).

When comparing the attractiveness of the dog and cat to mosquitoes, the larger number of captures were always from the dog, despite species composition. Ae. taeniorhynchus and Ae. scapularis were collected more frequently from the dog and much less than the cat. Even though the dog was more attractive than the cat to $C x$. quinquefasciatus, $C x$. declarator and $C x$. nigripalpus, the cat did attract these species to some extent, specially $C x$. quinquefasciatus (Table V). In Italy, according to Genchi et al. (1992), $C x$. pipiens, a closely related species to $C x$. quinquefasciatus, was the mosquito species most commonly associated with cats as well as dogs, which strengthens the possibility of members of the genus Culex being the potential vectors of $D$. immitis parasite to cats.

It should be pointed out that Ae. taeniorhynchus and Ae. scapularis were collected in large numbers in human-bait, while Culex species were collected much less frequently (Table V). This may be partially attributed to baits standing outdoors and under lighted conditions, while $C x$. quinquefasciatus are endophilic and nocturnal (Deane 1951, Rachou 1956) and to Aedes species being exophilic, aggressive, opportunistic and persistent blood-seekers (Rachou 1956, Forattini 1965, Edman \& Bidlingmayer 1969). It is important to note that the possible vectors of canine heartworm were attracted to humans, hence humans are exposed to dirofilariasis.

Ae. taeniorhynchus, Cx. quinquefasciatus, Ae. scapularis, $C x$. declarator and Cx. nigripalpus were more active during dusk when compared to dawn for all baits (Tables VI, VII). Culex species showed marked crepuscular activity while Aedes species were captured at daytime, although in smaller numbers when compared to dusk, such as noted before (Rachou 1956, Edman \& Bidlingmayer 1969, Lourenço-de-Oliveira \& da-Silva 1985). 
Heartworm disease in dogs in Rio de Janeiro is frequently reported in rural, suburban or urbanizing localities where wild and hemisynanthropic mosquito species are present. In urban localities of the State, where Cx. quinquefasciatus and Ae. aegypti are pratically the only species collected, the prevalence of canine heartworm is very low. For instance, in urban areas in the city of Rio de Janeiro, where $C x$. quinquefasciatus accounts for almost $94 \%$ of the mosquitoes collected in light traps, only $4.6 \%$ of dogs were infected. But the prevalence of heartworm disease increases to $12.5 \%$ in urbanizing districts within the city, where $C x$. quinquefasciatus accounts for only $58 \%$, while Ae. scapularis and the other mosquito species account for $25 \%$ and 17\%, respectively (FEEMA 1983, Labarthe et al. 1992, Souza 1992). Additionally, in contrast to the above districts, the prevalence of the disease increases to $52.5 \%$ in localities of low demographic density of the State (Labarthe et al. 1997a), such as Itacoatiara, where $C x$. quinquefasciatus accounts for only $25.5 \%$ of the total mosquitoes collected, while Ae. taeniorhynchus and Ae. scapularis account for approximately $30 \%$ and $20 \%$, respectively (Table I). These data suggest that wild and hemisynanthropic mosquito species such as $A e$. taeniorhynchus, Ae. scapularis, Cx. declarator and $C x$. nigripalpus might be the principal vectors of $D$. immitis, while the endophilic $C x$. quinquefasciatus seems likely to be, at most, a secondary vector. Ae. taeniorhynchus and Ae. scapularis have already been identified as potential vectors of $D$. immitis in Rio de Janeiro (Lourenço-de-Oliveira \& Deane 1995), and Ae. taeniorhynchus is considered a vector in the Americas (Sauerman \& Nayar 1983, Parker 1986, 1993, Lowrie 1991). Cx. declarator has never been mentioned as a potential vector of heartworm. $C x$. nigripalpus has been reported to be a vector (Sauerman \& Nayar 1983). Cx. quinquefasciatus is considered a competent vector by some workers (Kartman 1953, Villavaso \& Steelman 1970, Sauerman \& Nayar 1983, Russel 1985, Lowrie 1991) and as a secondary vector by others (Loftin et al. 1995). Despite being susceptible to $D$. immitis parasites (McCall et al. 1992), cats in the State of Rio de Janeiro are rarely infected. This may be partially explained by (1) the vector feeding behavior, since mosquitoes were most frequently collected from dogs, (2) the inability of cats to transmit filarial parasites to mosquitoes because of their low blood microfilaremia, (3) the distribution of mosquito species that bite cats at greater frequencies do not coincide with heartworm prevalence in the State of Rio de Janeiro, and (4) dogs are the principal reservoir host for transmission of the parasites to vector mosquitoes.

\section{ACKNOWLEDGMENTS}

To Monique Albuquerque Motta and Luciana R Barros for their help in identifying the Wyeomyia and Phoniomyia species. To Prof. Pedro Carvalho Rodrigues and Luciene Rodrigues Carvalho for performing the statistical analysis. To Ana Duék for reviewing of the manuscript and to Mara Lemos for the map.

\section{REFERENCES}

Apperson CS, Engber B, Levine JF 1989. Relative suitability of Aedes albopictus and Aedes aegypti in North Carolina to support development of Dirofilaria immitis. J Am Mosq Control Assoc 5: 377-382.

Aragão MB 1975. Sobre o comportamento de alguns insetos hematófagos. Arq Biol Tecnol 18: 3-23.

Bates M 1949. The Natural History of Mosquitoes, The Macmillan Co., New York, 378 pp.

Christensen BM 1977. Laboratory studies on the development and transmission of Dirofilaria immitis by Aedes trivittatus. Mosq News 37: 367-372.

Christensen BM 1978. Dirofilaria immitis: effect on the longevity of Aedes trivittatus. Exp Parasitol 44: 116123.

Christensen BM 1981. Observations on the immune response of Aedes trivittatus against Dirofilaria immitis. Trans $R$ Soc Trop Med Hyg 75: 439-443.

Consoli RAGB, Lourenço-de-Oliveira R 1994. Principais Mosquitos de Importância Sanitária no Brasil, Fiocruz, Rio de Janeiro, 228 pp.

Deane LM 1951. Observações sobre alguns hábitos dos adultos de Culex fatigans, o principal transmissor da filariose em Belém do Pará. Rev SESP 4: 423461.

Dillon AR 1986. Feline heartworm disease. In Proceedings of the Heartworm Symposium'86: 149-154, Washington, DC.

Dillon AR 1988. Feline heartworm disease, p. 205-215. In PFL Boreham \& RB Atwell (eds). Dirofilariasis, CRC Press, Boca Raton, Florida.

Donahoe JM 1975. Experimental infection of cats with Dirofilaria immitis. J Parasitol 61: 599-605.

Edman JD, Bidlingmayer WL 1969. Flight capacity of blood-engorged mosquitoes. Mosq News 29: 386392.

Elkins AD, Kadel W 1988. Feline heartworm disease and its incidence in Western Kentuky. Comp Cont Ed 10: 585-589.

FEEMA-Fundação Estadual de Engenharia do Meio Ambiente 1983. Comunicações de incidência mensal no Município do Rio de Janeiro em 1983.

Forattini OP 1965. Entomologia Médica 2, Universidade de São Paulo, São Paulo. 506 pp.

Forattini OP, Gomes AC, Natal D, Kakitani I, Marucci D 1987a. Preferências alimentares de mosquitos Culicidae no Vale do Ribeira, São Paulo, Brasil. Rev Saúde Públ São Paulo 21: 171-187.

Forattini OP, Gomes AC, Natal D, Kakitani I, Marucci D 1987b. Frequiência domiciliar e endofilia de mosquitos Culicidae no Vale do Ribeira, São Paulo, Brasil. Rev Saúde Públ São Paulo 21: 188-192.

Forattini OP, Kakitani I, Massad E, Marucci D 1993. Studies on mosquitoes (Diptera: Culicidae) and 
anthropic environment. 3 - Survey of adult stages at rice irrigation system and the emergence of Anopheles albitarsis in south-eastern, Brazil. Rev Saúde Públ São Paulo 27: 313-325.

Forattini OP, Kakitani I, Massad E, Marucci D 1995. Studies on mosquitoes (Diptera: Culicidae) and anthropic environment. 9 - Synanthropy and epidemiological vector role of Aedes scapularis in southeastern, Brazil. Rev Saúde Públ São Paulo 29: 199207.

Genchi C, Di Sacco B, Cancrini G 1992. Epizootiology of canine and feline heartworm infection in Northern Italy: possible mosquito vectors. In Proceedings of the Heartworm Symposium'92: 39-46, Austin, Texas.

Guerrero J, Ducos de la Hite J, Genchi,C, Rojo F, GomezBautista M, Varela MC, Labarthe N, Bordin E, Gonzalez G, Mancebo O, Patino F, Uribe LF, Samano R 1992a. Update on the distribution of Dirofilaria immitis in dogs from southern Europe and Latin America. In Proceedings of the Heartworm Symposium'92: 31-37, Austin, Texas.

Guerrero J, McCall JW, Dzimianski MT, McTier TL, Holmes RA, Newcomb KM 1992b. Prevalence of Dirofilaria immitis infection in cats from the southeastern United States. In Proceedings of the Heartworm Symposium'92: 91-95, Austin, Texas.

Haddow AJ 1954. Studies on the biting-habits of african mosquitoes: an apprasial of methods employed with special reference to the twenty-four-hour catch. Bull Ent Res 45: 199-242.

Haddow AJ 1960. Studies on the biting habits and medical importance of east african mosquitoes in the genus Aedes. Bull Ent Res 50: 759-779.

Kartman L 1953. Factors influencing infection of the mosquito with Dirofilaria immitis (Leidy, 1856). Exp Parasitol 2: 27-78.

Kasai N, Williams P 1986. Infecção experimental de Aedes fluviatilis (Lutz, 1904) por Dirofilaria immitis (Leidy, 1856). Rev Brasil Biol 46: 277-283.

Knight DH, Lok JB 1995. Seasonal timing of Heartworm chemoprophylaxis in the United States. In Proceedings of the Heartworm Symposium'95: 37-42, Auburn, Alabama.

Konishi E 1989a. Culex tritaeniorhynchus and Aedes albopictus (Diptera: Culicidae) as natural vectors of Dirofilaria immitis (Spirurida: Filariidae) in Miki City, Japan. J Med Entomol 26: 294-300.

Konishi E 1989b. Susceptibility of Aedes albopictus and Culex tritaeniorhynchus (Diptera: Culicidae) collected in Miki City, Japan, to Dirofilaria immitis (Spirurida: Filariidae). J Med Entomol 26: 420-423.

Labarthe N, Almosny N, Guerrero J, Duque-Araujo AM 1997a. Description of the occurrence of canine Dirofilariasis in the State of Rio de Janeiro, Brazil. Mem Inst Oswaldo Cruz 92: 47-51.

Labarthe N, Ferreira AMR, Guerrero J, Newkomb K, Paes-de-Almeida E 1997b. Survey of Dirofilaria immitis (Leidy, 1856) in random source cats in metropolitan Rio de Janeiro, Brazil, with description of lesions. Vet Parasitol, in press.

Labarthe NV, Almosny NR, Soares AM, Souza-Silva
LC 1992. Update on the distribution of Dirofilaria immitis in the State of Rio de Janeiro, Brazil. Proceedings of the XVII WSAVA World Congress: 291293, Rome, Italy.

Lane J 1953. Neotropical Culicidae, 2 vol., Universidade de São Paulo, São Paulo, Brazil, 1112 pp.

Loftin KM, Byford RL, Loftin MJ, Craig ME 1995. Potential mosquito vectors of Dirofilaria immitis in Bernadillo County, New Mexico. J Am Mosq Control Assoc 11: 90-93.

Lourenço-de-Oliveira R, Deane LM 1995. Presumed Dirofilaria immitis infections in wild-caught Aedes taeniorhynchus and Aedes scapularis in Rio de Janeiro, Brazil. Mem Inst Oswaldo Cruz 90: 387388.

Lourenço-de-Oliveira R, da-Silva TF 1985. Alguns aspectos da ecologia dos mosquitos (Diptera: Culicidae) de uma área de planície (Granjas Calábria), em Jacarepaguá, Rio de Janeiro. III. Preferência horária das fêmeas para o hemofagismo. Mem Inst Oswaldo Cruz 80: 195-201.

Lourenço-de-Oliveira R, da-Silva TF, Heyden R 1985. Alguns aspectos da ecologia dos mosquitos (Diptera: Culicidae) de uma área de planície (Granjas Calábria), em Jacarepaguá, Rio de Janeiro. II. Freqüência mensal e no ciclo lunar. Mem Inst Oswaldo Cruz 80: 123-133.

Lowrie RC 1991. Poor vector efficiency of Culex quinquefasciatus following infection with Dirofilaria immitis. J Am Mosq Control Assoc 7: 30-36.

Ludlam KW, Jachwski LA, Otto GF 1970. Potential vectors of Dirofilaria immitis. JAVMA 157: 1354-1359.

McCall JW, Dzimianski MT, McTier TL, Jernigan AD, Jung JJ, Mansour AE, Supakorndej P, Plue RE, Clark JN, Wallace DH, Lewis RE 1992. Biology of experimental heartworm infections in cats. In Proceedings of the Heartworm Symposium'92: 71-79, Austin, Texas.

Otto GF, Jachowski Jr LA 1980. Mosquitoes and canine heartworm disease. In Proceedings of the Heartworm Symposium '80: 17-32, Dallas, Texas.

Parker BM 1986. Presumed Dirofilaria immitis infections from field-collected mosquitoes in North Carolina. J Am Mosq Control Assoc 2: 231-233.

Parker BM 1993. Variation in mosquito (Diptera: Culicidae) relative abundance and Dirofilaria immitis (Nematoda: Filarioidea) vector potential in coastal North Carolina. J Med Entomol 30: 436-442.

Rachou RG 1956. Transmissores da filariose bancroftiana no Brasil. Rev Bras Malariol D Trop 8: 267-279.

Rodrigues PC 1993. Bioestatística, 2nd ed., EDUFF, Niterói, RJ, 268 pp.

Russel RC 1985. Report of a field study on mosquito (Diptera: Culicidae) vectors of dog heartworm, Dirofilaria immitis Leidy (Spirurida: Onchocercidae) near Sydney, NSW, and the implications for veterinary and public health concern. Aust J Zool 33: 461-472.

Sauerman DM, Nayar JK 1983. A survey for natural potential vectors of Dirofilaria immitis in Vero Beach, Florida. Mosq News 43: 222-225.

Souza SSHVC 1992. Diagnóstico da Dirofilariose 
154 Mosquitoes in a Canine Dirofilariasis Area in Brazil - Norma Labarthe et al.

através da Detecção de Antígenos Circulantes em Cães no Estado do Rio de Janeiro, MSc. Thesis, Faculdade de Veterinária, Universidade Federal Rural do Rio de Janeiro, Rio de Janeiro, 87 pp.

Villavaso EJ, Steelman CD 1970. Laboratory and field studies of the southern house mosquito, Culex pipiens quinquefasciatus Say, infected with the dog heart- worm, Dirofilaria immitis (Leidy), in Louisiana. $J$ Med Ent 7: 471-476.

Williams CB 1937. The use of logarithms in the interpretation of certain entomological problems. Ann Appl Biol 24: 404-414.

Wong MM, Pederson NC, Cullen J 1983. Dirofilariasis in cats. J Am Anim Hosp Assoc 19: 855-864. 